\title{
The influences of pollution sources on the vertical distributions of As in Jiaozhou Bay waters
}

\author{
Dongfang Yang ${ }^{1,2,3, a}$, Sixi Zhu ${ }^{1,2}$, Fengyou Wang ${ }^{1,2, b}$, Yunjie $\mathrm{Wu}^{1,2}$ and Xiuqin \\ Yang $^{1,2}$ \\ ${ }^{1}$ Research Center for Karst Wetland Ecology, Guizhou Minzu University, Guizhou Guiyang, \\ Guizhou Guiyang, China \\ ${ }^{2}$ College of Chemistry and Environmental Science, Guizhou Minzu University, Shanghai, 550025, \\ China \\ ${ }^{3}$ North China Sea Environmental Monitoring Center, SOA, Qingdao 266033, China \\ adfyang_dfyang@126.com; ${ }^{b}$ Corresponding author; 'wangfy2001@yahoo.com.cn
}

Keywords: As; Pollution sources; Vertical distributions; Seasonal variations; Influences; Jiaozhou Bay.

\begin{abstract}
Based on the investigation data on As in surface and bottom waters in the bay mouth of Jiaozhou Bay in 1983, this paper analyzed the seasonal variations, vertical variations and horizontal distributions of As. Results showed that As contents in surface waters in different seasons were in order of summer $>$ autumn $>$ spring, while in bottom waters were autumn $>$ spring $>$ summer. The horizontal distributions of As in surface and bottom waters were consistent in May, while in September and October were reverse. We found that the vertical distributions of As and were mainly determined by the influences of pollution sources.
\end{abstract}

\section{Introduction}

As-containing waste water is one of the world widely industrial waster waters, and is causing environmental pollution issues in soil, rivers, ground waters and coastal waters in many countries, especially in developing countries. Due to the high toxicity of As, the As pollution in the marine environment could finally cause harms to human beings. Hence, studying the seasonal variation and spatial distributions of As in the marine environment is essential to understand the pollution level and environmental impact [1-3].

\section{Materials and method}

Jiaozhou Bay $\left(35^{\circ} 55^{\prime}-36^{\circ} 18^{\prime} \mathrm{N}, 120^{\circ} 04^{\prime}-120^{\circ} 23^{\prime} \mathrm{E}\right)$ is located in the south of Shandong Peninsula, eastern China. The area and and average water depth are $460 \mathrm{~km}^{2}$ and $7 \mathrm{~m}$, respectively, yet the bay mouth is only $2.5 \mathrm{~km}$ (Fig. 1). This bay is surrounding by cities of Qingdao, Jiaozhou and Jiaonan in the east, north and south, and is connected with the Yellow Sea in the south. There are more than ten inflow rivers such as Loushan River, Licun River and Haibo River, all of which are seasonal rivers [4-5].

The investigation on As in five sampling sites (H34, H35, H36, H37 and H82) in Jiaozhou Bay waters was conducted by North China Sea Environmental Monitoring Center in May, September and October 1983 (Fig. 1). The investigation and measurement of As were follow by National Specification for Marine Monitoring [6]. We defined May, September and October as spring, summer and autumn, respectively. 


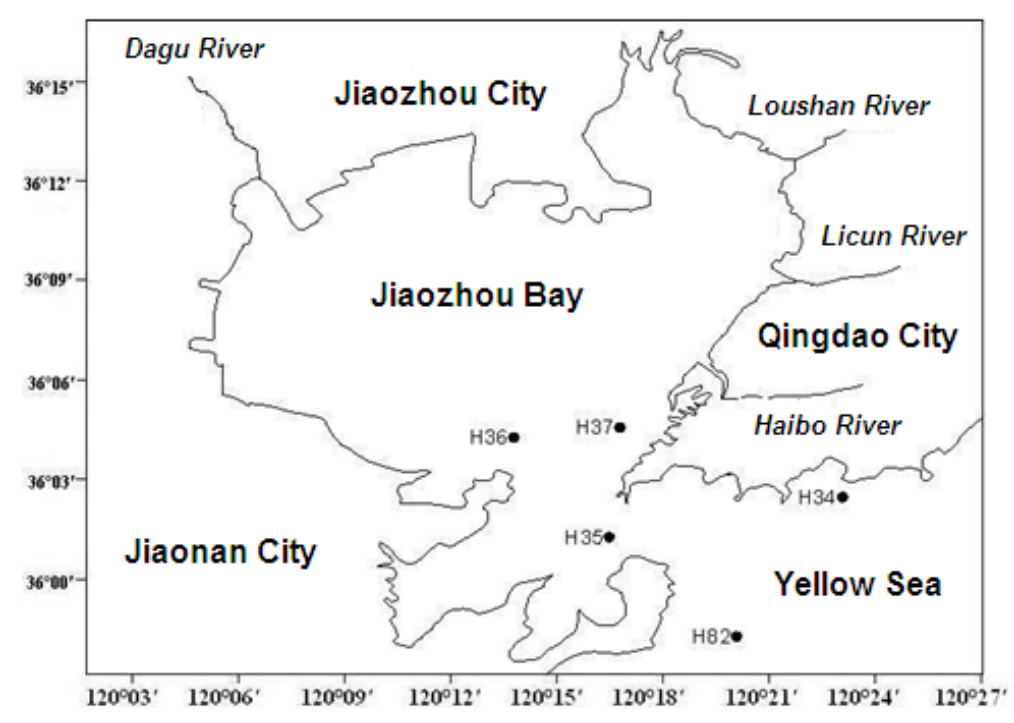

Fig.1 Geographic location and sampling sites of Jiaozhou Bay

\section{Results and discussion}

\section{Seasonal variations of As.}

As contents in surface waters in the bay mouth of Jiaozhou Bay in May, September and October 1983 were ranged from 1.52-4.30 $\mu \mathrm{g} \mathrm{L}^{-1}, 0.19-1.59 \mu \mathrm{g} \mathrm{L}^{-1}$ and 0.71-2.93 $\mu \mathrm{g} \mathrm{L}^{-1}$, respectively, and were ranged from $0.19-4.30 \mu \mathrm{g} \mathrm{L}^{-1}$ in the whole year. The major sources of As in spring in Jiaozhou Bay were overland runoff, stream flow, and marine current, whose source strengths of the pollution sources were relative high. In summer, the major sources of As were stream flow and marine current, and the source strength of stream flow was decreased to a low level along with the transfer process from the estuaries of the major rivers to the bay mouth. Hence, As contents was relative low in summer. In autumn, the major sources were overland runoff and marine current, and the overland runoff were mainly generated from the overland runoff from the coastal regions around the bay mouth. Hence, As contents in autumn were relative high. In generally, As contents in surface waters were mainly determined by overland runoff and stream flow.

In bottom waters in May, September and October 1983, As contents were ranged from 1.08-1.74 $\mu \mathrm{g} \mathrm{L}{ }^{-1}, 0.15-2.30 \mu \mathrm{g} \mathrm{L}^{-1}$ and $0.44-1.48 \mu \mathrm{g} \mathrm{L}{ }^{-1}$, respectively, and were ranged from $0.15-2.30 \mu \mathrm{g} \mathrm{L}^{-1}$ in the whole year. By means of vertical waters's effect [7], As contents in bottom waters were mainly determined by which in surface waters, and there were sedimentation and accumulation processes in the waters $[2,5]$. Therefore, As contents were also high in bottom waters in summer in case of high As contents in surface waters in spring, as contents were lower in bottom waters in autumn in case of low As contents in surface waters in summer. Hence, As contents in surface waters in different seasons were in order of summer $>$ autumn $>$ spring, while in bottom waters were autumn > spring > summer. However, in according to the guide line of Class I for As (20.00 $\mu \mathrm{g} \mathrm{L}^{-1}$ ) in National Standard of China for Seawater Quality (GB3097-1997), the pollution level of As in Jiaozhou Bay in 1983 was very low.

\section{Horizontal variations of As.}

The five sampling sites were located in the inner side (H36 and H37), middle (H35) and out side (H34 and H82) of the bay mouth. In surface waters in May, As contents were decreasing from the inner side $\left(4.89 \mu \mathrm{g} \mathrm{L}^{-1}\right)$ to the out side $\left(1.52 \mu \mathrm{g} \mathrm{L}^{-1}\right)$, while in bottom waters were increasing from the inner side $\left(1.56 \mu \mathrm{g} \mathrm{L}^{-1}\right)$ to the out side $\left(1.74 \mu \mathrm{g} \mathrm{L}^{-1}\right)$. In surface waters in September, As contents were decreasing from the inner side $\left(0.74 \mu \mathrm{g} \mathrm{L}^{-1}\right)$ to the out side $\left(0.19 \mu \mathrm{g} \mathrm{L}^{-1}\right)$, and in bottom waters were decreasing from the inner side $\left(0.63 \mu \mathrm{g} \mathrm{L}^{-1}\right)$ to the out side $\left(0.15 \mu \mathrm{g} \mathrm{L}^{-1}\right)$. In surface waters in October, As contents were decreasing from the inner side $\left(2.93 \mu \mathrm{g} \mathrm{L}^{-1}\right)$ to the out side $\left(1.48 \mu \mathrm{g} \mathrm{L}^{-1}\right)$, and in bottom waters were decreasing from the inner side $\left(0.52 \mu \mathrm{g} \mathrm{L}^{-1}\right)$ to the out side $\left(0.44 \mu \mathrm{g} \mathrm{L}^{-1}\right)$. The horizontal distributions of As in surface and bottom waters were consistent in May, while in 
September and October were reverse.

In order to reveal the vertical variations of As, As contents in surface waters in the five sampling sites were subtracted by which in bottom waters, and the results were listed in Table 1 . The

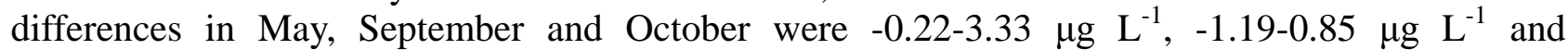
-0.29-2.41 $\mu \mathrm{g} \mathrm{L}^{-1}$. In generally, As contents in surface waters and bottom waters were closed, and As contents in bottom waters were increasing/decreasing along with the increasing/decreasing of which in surface waters.

Table 1 The minus of the As contents between the surface and bottom layers in the Jiaozhou bay mouth waters

\begin{tabular}{|c|c|c|c|c|c|}
\hline & H36 & H37 & H35 & H34 & H82 \\
\hline May & Positive & Positive & Negative & Positive & Positive \\
\hline September & Positive & Positive & Positive & Negative & Positive \\
\hline October & Positive & Zero & Positive & Negative & Negative \\
\hline
\end{tabular}

\section{Vertical variations of As.}

By means of the vertical waters's effect [7], As contents were changing alot after pass through the water body. The growth and reproduction of marine planton were incrasing in spring and reach the climax in summer [5], and a large amount of colloid was generated in the surface of the suspended particulate matters. Hence, the absorption and sedimentation of As in waters were also increasing [2].

The major sources of As in May were overland runoff, marine current and stream flow. The input directions of overland runoff and stream flow were from the inner side of bay to the out side of the bay, while for marine current were inverse. By means of the overlay of the three sources, the horizontal distributions of As contents in surface and bottom waters in spring were reverse. In September and October, the horizontal distributions of As contents in surface and bottom waters were consist, because a big part of As were transferred to bottom waters by means of sedimentation.

\section{Regional variations of As.}

Once were input to the bay by overland runoff and stream flow, As was originally arrived the surface waters, and then was transferred to bottom waters rapidly and continously. Site H36 was located in the southwest inside the bay, in where As contents were always higher in surface waters than in bottom waters in different seasons, because the major source of As in this area was stream flow.

For Site H37, As contents were always higher in surface waters than in bottom waters in May and Septemer, due to the input of stream flow. However, As contents in Site H37 in surface waters and bottom waters were same in October by means of the homogeneity of marine waters [8]. Site H35 was located in the bay mouth, in where the directions of overland runoff and stream flow were from the inner side to the out side of the bay, while for marine current was inverse. Hence, As contents in surface waters were lower than in bottom waters in Site H35 in May, and were inverse in September and October. Site H34 and H82 were located in the out side of the bay, in where the major source was marine current. Hence, in case of the influence of marine current was strong (in May), As contents in surface waters were higher than in bottom waters. Once the influence of marine current was weak (in September and October), As contents in surface waters were lower than in bottom waters.

\section{Conclusion}

As contents in surface waters in different seasons were in order of summer $>$ autumn $>$ spring, while in bottom waters were autumn $>$ spring $>$ summer. The horizontal distributions of As in surface and bottom waters were consistent in May, while in September and October were reverse. The major sources of As in May were overland runoff, marine current and stream flow. The input directions of overland runoff and stream flow were from the inner side of bay to the out side of the bay, while for marine current were inverse. The vertical distributions of As and were mainly 
determined by the influences of pollution sources and the vertical waters's effect.

\section{Acknowledgement}

This research was sponsored by Doctoral Degree Construction Library of Guizhou Nationalities University, Education Ministry's New Century Excellent Talents Supporting Plan (NCET-12-0659), Education Ministry's New Century Excellent Talents Supporting Plan (NCET-12-0659), Project of Outstanding Technological Educators of Governor of Guizhou ([2012]71), Project of Low Carbon Technology Plan of Guiyang (2012205]), Project of Science and Technology Foundation of Guiyang (LKM[2012]05), Special Research Projects of High Level Talents of Guizhou Province (TZJF-2011-44), the China National Natural Science Foundation (31560107) and Research Projects of Guizhou Nationalities University ([2014]02), Research Projects of Guizhou Province Ministry of Education (KY [2014] 266), Research Projects of Guizhou Province Ministry of Science and Technology (LH [2014] 7376).

\section{Reference}

[1] Yang DF, Song WP, Chen ST, et al.:, Coastal Engineering, Vol. 31(2012), p. 47-55. (in Chinese)

[2] Yang DF, Zhao YH, Pu ZG, et al.: Ocean Development and Management, Vol. 31 (2014), p. 109-112. (in Chinese)

[3] Yang DF, Zhu SX, Wang FY, et al.:Meterological and Environmental Research, Vol. 5(2014), p. 24-26.

[4] Yang DF, Chen Y, Gao ZH, et al.: Chinese Journal of Oceanology and Limnology, Vol. 23 (2005), pp. 72-90.

[5] Yang DF, Wang F, Gao ZH, et al.: Marine Science, Vol. 28 (2004), p. 71-74. (in Chinese)

[6] State Ocean Administration. The specification for marine monitoring: Beijing, Ocean Precess, (1991).

[7] Yang DF, Wang FY, He HZ, et al.: Proceedings of the 2015 international symposium on computers and informatics, 2015, p. 2655-2660.

[8] Yang DF, Ding ZR, Zheng L, et al.:Coastal Engineering, Vol. 30(2011), p. 66-74. (in Chinese) 